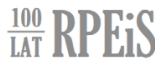

\section{PRAWO UNII EUROPEJSKIEJ W POLSKICH CZASOPISMACH PRAWNICZYCH (KILKA OBSERWACJI)}

I. Poniższe rozważania nie mają na celu dać całościowego obrazu piśmiennictwa z dziedziny prawa unijnego w polskich czasopismach. Stworzenie takiego obrazu dotyczącego rozległej problematyki wymagałoby dłuższych analiz po zebraniu i wykorzystaniu obszernej dokumentacji. Okazało się to niemożliwe w czasie pandemii koronawirusa, kiedy dostęp do bibliotek jest znacznie utrudniony. Wobec tego dalsze refleksje będą oparte na uogólnionych spostrzeżeniach poczynionych na podstawie lektur. Chociaż uwaga zostanie skupiona na czasopismach, wiele spostrzeżeń może być aktualnych także $\mathrm{w}$ odniesieniu do prac zbiorowych $\mathrm{w}$ formie książek.

Prawo Unii Europejskiej (wcześniej: Wspólnoty Europejskiej) jest chyba najmłodszą dziedzina nauki prawa uprawiana w naszym kraju. Artykuły dotyczące tej problematyki zaczęły się pojawiać na szerszą skalę w polskich czasopismach prawniczych na przełomie lat osiemdziesiątych i dziewięćdziesiątych XX w. Trzeba przy tym zaznaczyć, że artykuły na temat Europejskiej Wspólnoty Gospodarczej i różnych zagadnień europejskiego prawa wspólnotowego były obecne już wcześniej w czasopismach lub rozmaitych biuletynach począwszy od końca lat pięćdziesiątych. Nie były jednak liczne i odnosiły się do różnych nowych wówczas zagadnień, dotyczących na przykład organizacji i funkcjonowania wspólnot, pozycji państw członkowskich i wybranych aspektów wspólnego rynku. Ówczesne publikacje były utrzymane w konwencji prawa międzynarodowego, a zwłaszcza prawa organizacji międzynarodowych albo międzynarodowego prawa gospodarczego.

Wzrost popularności omawianej problematyki począwszy od przełomu lat osiemdziesiątych i dziewięćdziesiątych był zrozumiały. Dokonane wówczas zmiany ustrojowe sprawiły, że realna stała się perspektywa nawiązania

\footnotetext{
"Stanisław Biernat, Uniwersytet Jagielloński, stanislaw.biernat@uj.edu.pl, https://orcid.org/0000-0001-8923-0766,

Redaktor naczelny czasopisma „Europejski Przegląd Sądowy”.
} 
formalnych więzów Polski ze Wspólnotami Europejskimi (a wkrótce potem: z Unią Europejska), początkowo w formie stowarzyszenia i kandydowania do członkostwa, a potem samego członkostwa w Unii.

Wzmożenie zainteresowania omawianą problematyka w czasopismach przejawiało się nie tylko w coraz większej liczbie publikacji, ale też w innym niż poprzednio podejściu ze strony autorów. Tak więc wcześniej, do końca lat osiemdziesiątych, artykuły w czasopismach poświęcone Wspólnotom Europejskim odnosiły się do organizacji międzynarodowej, do której Polska nie należała ani nie miała szans należeć. Prace miały zatem głównie charakter informacyjny o obcym porządku prawnym. Po 1989 r. perspektywa uległa natomiast zmianie ze względu na aspiracje Polski do stowarzyszenia i członkostwa. Zaczęły się pojawiać także artykuły poświęcone prawu wspólnotowemu (unijnemu) w kontekście prawa polskiego.

Charakterystyczne było podejmowanie nowych tematów i nowe spojrzenie w miarę postępów procesu zacieśniania się integracji europejskiej z udziałem Polski. W pierwszym okresie po zmianach ustrojowych popularne były zagadnienia stowarzyszenia z Wspólnotami i ich państwami członkowskimi. Dotyczyły między innymi samego pojęcia stowarzyszenia, procedury jego ustanawiania, praw i obowiązków z tym związanych, a także relacji między stowarzyszeniem a członkostwem w Unii. Jednym z ważniejszych tematów przez kilkanaście lat było zbliżanie prawa polskiego do standardów prawa europejskiego, najpierw jako wymaganie wynikające z Układu Europejskiego (stowarzyszeniowego), a następnie jako warunek przystapienia do Unii. Artykuły dotyczyły zarówno samego pojęcia i mechanizmów zbliżania prawa (używano też często określenia: harmonizacja), jak i analizy jego przebiegu oraz rezultatów zmian w poszczególnych dziedzinach polskiego prawa.

Następnym popularnym kompleksem zagadnień artykułów w czasopismach były w początkowym okresie aspekty prawne przystępowania Polski do Unii Europejskiej. Mieściły się w tym zarówno problemy proceduralne akcesji, jak i wymagania stawiane państwom przystępującym i charakter oraz treść traktatu i aktu akcesyjnego. Problemy prawne akcesji były analizowane zarówno z perspektywy prawa unijnego, jak i prawa polskiego (np. podstaw konstytucyjnych przyszłego członkostwa w Unii, a także procedury ratyfikacyjnej, ze szczególnym uwzględnieniem referendum).

Należy przy tym mieć na względzie, że w omawianych „pionierskich” latach nie było praktycznie dostępnych materiałów w języku polskim. Stopniowo dopiero pojawiały się nieoficjalne i nie w pełni zadowalające tłumaczenia traktatów. Niedostępne były polskie wersje aktów wspólnotowego (unijnego) prawa pochodnego czy innych dokumentów. Niewiele lepiej było zresztą z dostępnością materiałów obcojęzycznych; należy pamiętać, że było to w epoce przedinternetowej. Te okoliczności tłumacza także, dlaczego publikacje miały początkowo często charakter opisowy i sprawozdawczy. Artykuły w czasopismach prawniczych zastępowały podręczniki.

Warto przypomnieć na marginesie, że pierwsze polskie podręczniki prawa wspólnotowego (unijnego) pojawiły się w połowie lat dziewięćdziesiątych. Wtedy też, albo kilka lat później, rozpoczęło się systematyczne nauczanie 
prawa europejskiego na wydziałach prawa polskich uniwersytetów w ramach kursu prawa międzynarodowego lub jako osobny przedmiot, często w niewielkim wymiarze godzin, albo jako przedmiot do wyboru.

II. Dokonując przeskoku w czasie, można scharakteryzować w wielkim skrócie obecność problematyki prawa Unii Europejskiej w aktualnie wydawanych w Polsce czasopismach prawniczych.

Publikacje z dziedziny prawa unijnego w czasopismach nie różnią się co do formy od prac z innych dziedzin prawa. Są to przede wszystkim artykuły, których objętość waha się w praktyce, w zależności od limitów przewidzianych w danym czasopiśmie, od kilku do kilkudziesięciu stron, oraz glosy do orzeczeń. Prace z dziedziny prawa unijnego ukazują się w wielu czasopismach. Trudno byłoby ustalić ich liczbę i treść bez żmudnego przeglądania zawartości poszczególnych numerów. Można jednak pokusić się o kilka spostrzeżeń i uogólnień.

Liczną grupę tworzą czasopisma wielotematyczne, nieskupiające się na określonej tematyce. Sa w nich zamieszczane publikacje z różnych dziedzin prawa. Wśród nich znajduja się także artykuły lub glosy z prawa unijnego. Niektóre z tych czasopism mają zasięg ogólnopolski i są znane wśród czytelników (np. „Państwo i Prawo”, „Ruch Prawniczy, Ekonomiczny i Socjologiczny”, „Forum Prawnicze”). Ponadto liczne czasopisma są związane wydziałami lub instytutami prawa uniwersytetów i innych uczelni wyższych oraz organizacji naukowych. Trzeba stwierdzić, że w ogólnej puli materiałów publikowanych w poszczególnych czasopismach należących do tej grupy nie ma wiele prac z zakresu prawa unijnego, ale w sumie przynoszą one pewien zasób wiedzy $\mathrm{z}$ omawianej dziedziny prawa.

Inną grupę stanowią czasopisma bardziej sprofilowane tematycznie, np. w kierunku prawa konstytucyjnego, sądowego, publicznego, administracyjnego, gospodarczego, pracy i socjalnego, podatkowego, własności intelektualnej, rolnego czy karnego. Do tego można dodać czasopisma specjalizujące się w tematyce bliskiej przedstawicielom określonych zawodów prawniczych, np. adwokatom czy radcom prawnym. Także w tych czasopismach sa zamieszczane z różną częstotliwością artykuły albo glosy z prawa unijnego. W niektórych czasopismach publikowane są regularnie przeglądy orzecznictwa Trybunału Sprawiedliwości (np. „Przegląd Podatkowy”, „Zeszyty Naukowe Sądownictwa Administracyjnego").

Kilka czasopism specjalizuje się w zagadnieniach prawa międzynarodowego oraz prawa unijnego i zamieszcza artykuły z obu tych dziedzin, jakkolwiek raczej z przewaga problematyki prawa międzynarodowego (np. „Sprawy Międzynarodowe”, „Problemy Współczesnego Prawa Międzynarodowego Europejskiego i Porównawczego").

Obok czasopism prawniczych należy odnotować także czasopisma interdyscyplinarne z zakresu europeistyki (np. „Studia Europejskie”, „Przegląd Europejski”). Przeważa w nich problematyka politologiczna lub ekonomiczna, ale zagadnienia prawne są także reprezentowane.

W okresie po 1989 r. występowały czasopisma specjalizujące się w prawie europejskim. Miały różny charakter: albo informacyjny („Prawo Europejskie 
w Praktyce), albo naukowy („Przegląd Prawa Europejskiego”, „Studia Prawno-Europejskie"). Obecnie wymienione wyżej periodyki nie są już wydawane. Od 2005 r. ukazuje się miesięcznik „Europejski Przegląd Sądowy”, poświęcony problematyce prawa europejskiego: unijnego i konwencyjnego, w szerszym zakresie, niż mogłoby to wynikać z jego tytułu.

Na podstawie powyższej skrótowej charakterystyki można skonstatować, że artykuły i glosy z zakresu prawa unijnego sa rozproszone w różnych miejscach. Niektóre czasopisma oprócz form papierowych sa oferowane czytelnikom elektronicznie na zasadzie otwartego dostępu. Rozproszenie publikacji $\mathrm{z}$ prawa unijnego lub z prawa polskiego, ale $\mathrm{z}$ elementami unijnymi w wielu polskich czasopismach świadczy o aktualności i popularności tej problematyki oraz o dużej liczbie i zróżnicowanych specjalizacjach autorów, wybierających różne miejsca dla zamieszczania swoich prac. Mnogość obecnych na rynku wydawniczym czasopism powoduje relatywną łatwość publikowania, co niekiedy się może odbić na poziomie zamieszczanych materiałów. W niektórych przypadkach nie ma wyraźnej zależności między miejscem publikacji a jej treścią; jest to przy tym stwierdzenie faktu, a nie zarzut. Może to być jednak praktycznym utrudnieniem dla czytelników szukających literatury na interesujące ich tematy. Przydatne sa w takich sytuacjach elektroniczne bibliografie (Lex, Legalis). Kilka lat temu zaprzestano zamieszczania w miesięczniku „Państwo i Prawo" popularnej Bibliografii Prawniczej.

III. Ze względu na krag czytelników artykuły i glosy są publikowane w czasopismach przede wszystkim $\mathrm{w}$ języku polskim. Jest to w pełni zrozumiałe, jakkolwiek utrudnia praktycznie korzystanie z takich publikacji przez czytelników z innych państw. Wiadomo, że światowym językiem nauki stał się język angielski. Dotyczy to także nauk prawnych; również w naszym kraju język angielski zdetronizował w znacznej mierze przeważające w przeszłości języki niemiecki czy francuski. Z tego względu polscy autorzy publikują coraz częściej za granicą. To zagadnienie pozostaje poza zakresem niniejszego opracowania.

Ponadto w polskich czasopismach pojawiają się coraz częściej publikacje w języku angielskim. Dotyczy to także artykułów i glos z prawa unijnego albo $\mathrm{z}$ prawa polskiego z elementami prawa unijnego. Zamieszczane sa także prace w innych językach, ale dla uproszczenia nie będzie o nich osobno mowy. Należy przy tym odnotować różne spotykane w tym względzie rozwiązania.

Pierwsze z nich polega na coraz bardziej rozpowszechnionym wydawaniu polskich czasopism zawierających $\mathrm{w}$ całości publikacje w języku angielskim. Są to czasopisma o różnym zasięgu tematycznym i częstotliwości ukazywania się. W niektórych $\mathrm{z}$ nich jest także obecne prawo unijne (chociaż raczej rzadko) obok innych dyscyplin prawniczych, niekiedy także obok zagadnień politologicznych albo ekonomicznych dotyczących Europy (np. „Polish Yearbook of International Law”, „Polish Review of International and European Law”, „Yearbook of Polish European Studies”, „Review of European and Comparative Law”, „Yearbook of Antitrust and Regulatory Studies” (YARS), „Krytyka Prawa”, „Comparative Law Review”, „Studia Iuridica Lubliniensia”, „Acta Iuris Stetinensis"). 
Wydawanie takich czasopism należy ocenić jednoznacznie pozytywnie. Przyczyniają się one bezpośrednio do włączania polskiej literatury prawniczej i tym samym naszej nauki prawa do międzynarodowego obiegu. Warunkiem powodzenia takich przedsięwzięć jest wysoki poziom publikacji, a ponadto zapewnienie informacji o czasopismach i dobra dystrybucja, tj. dostępność tych czasopism w międzynarodowych bazach danych, bibliotekach, a przede wszystkim coraz powszechniejszy otwarty dostęp do nich w Internecie.

Drugim rozwiązaniem jest publikowanie wybranych numerów czasopism $\mathrm{w}$ języku angielskim, podczas kiedy inne numery zwieraja prace $\mathrm{w}$ języku polskim (np. „Studia Iuridica”, „Przegląd Prawa Konstytucyjnego”, „Białostockie Studia Prawnicze"). Zalety tego rozwiązania są zbliżone do tego, co zostało powiedziane wyżej, z tym że decydujace jest dostarczenie informacji w międzynarodowych bazach danych o publikacji poszczególnych numerów czasopism w języku angielskim.

Kolejne rozwiązanie polega na publikowania w poszczególnych numerach czasopism niektórych artykułów w języku polskim, a innych w języku angielskim, w tym także artykułów z prawa unijnego („Prace z Prawa Własności Intelektualnej”, „The Review of European Affairs”, „Adam Mickiewicz University Law Review”, „Praca i Zabezpieczenie Społeczne”, „Przegląd Prawa Rolnego”, „Krakowskie Studia Międzynarodowe”). Proporcje publikacji w języku polskim i języku angielskim mogą być w praktyce różne. Ocena takiego przedsięwzięcia może być zróżnicowana. Z jednej strony jest to, podobnie jak w sytuacjach omówionych wyżej, upowszechnianie w języku angielskim polskiego wkładu w dziedzinie prawa, w tym niekiedy także prawa unijnego. Z drugiej jednak strony powstaje konieczność zadbania, aby angielskojęzyczne publikacje w czasopismach zamieszczone między publikacjami w języku polskim, niekiedy reprezentujące wysoki poziom, zdołały dotrzeć do pożądanych, potencjalnych czytelników. Decydujące wydaje się umieszczanie zawartości omawianych czasopism w międzynarodowych bazach danych i bibliografiach.

Wreszcie często spotykanym zabiegiem, który można uznać za minimum przy redagowaniu czasopism, jest zamieszczanie spisów treści publikacji i abstraktów w języku angielskim. Daje to możliwość obcojęzycznej publiczności wstępnego zorientowania się, o czym pisze się i dyskutuje w Polsce.

IV. Trudno byłoby zbiorczo scharakteryzować autorów publikacji z prawa unijnego zamieszczanych w czasopismach. W pierwszym okresie po $1989 \mathrm{r}$. stosunkowo częste były prace autorów zagranicznych między innymi będące tłumaczeniami tekstów z czasopism obcojęzycznych lub wygłaszanych referatów. Obecnie również występują artykuły autorów z zagranicy, które są zamieszczane w czasopismach po polsku albo w językach oryginalnych.

Od początku omawianego okresu, tj. od końca lat osiemdziesiątych, a niekiedy nawet wcześniej, coraz liczniejsi polscy autorzy zaczynali się specjalizować w dziedzinie prawa wspólnotowego (unijnego). Odbywało się to zazwyczaj równolegle z uprawianiem ich wcześniejszych dyscyplin prawniczych. Najczęściej dotyczyło to specjalistów z prawa międzynarodowego, ale ponadto także 
z prawa konstytucyjnego i innych dyscyplin. Stopniowo dla wielu autorów prawo unijne stawało się główną uprawianą dziedzina, dyscyplina, a dla młodszych - nawet jedyna, co skądinąd nie jest korzystne.

Nagły wzrost zainteresowania prawem unijnym, wywołany przez omówione już okoliczności polityczne, wymusił początkowo przyspieszone zdobywanie wiedzy w omawianej dziedzinie przez polskich prawników. Jak wiadomo, w tradycyjnych dyscyplinach prawniczych rozwój kwalifikacji naukowych następuje zazwyczaj stopniowo, poprzez przygotowywanie kolejnych prac, zdobywanie stopni naukowych itd. W przypadku prawa unijnego natomiast, zwłaszcza w pierwszych latach, ten, wydawałoby się, naturalny porządek w pewnej mierze się odwrócił: autorami licznych publikacji, nie tylko artykułowych, byli młodzi, niekiedy nawet początkujący autorzy (m.in. zdobywający wiedzę z zakresu prawa europejskiego w czasie zagranicznych stypendiów).

W miarę upływu czasu rozszerzał się krag autorów publikujących w czasopismach prace z omawianej dziedziny. Można stwierdzić, że obecnie sa to w dużej mierze osoby, które swoje pierwsze kontakty z prawem unijnym mogły mieć w toku swoich studiów prawniczych. Wielu autorów publikacji w czasopismach uzyskało stopnie naukowe z tej dziedziny.

Wśród autorów przeważają akademicy, spotyka się jednak także prawników praktyków: sędziów, adwokatów, radców prawnych, a także urzędników różnych szczebli, łącznie z unijnym.

V. Na krótkie omówienie zasługują sposoby podejścia do problematyki prawa unijnego w publikacjach zamieszczanych w czasopismach.

Przeważają opracowania dogmatycznoprawne. Autorzy analizują w nich przepisy i konstrukcje prawa unijnego, pierwotnego lub pochodnego. Rozważania są albo opisowe, albo bardziej pogłębione i problemowe, często w nawiązaniu do orzecznictwa i innych przejawów stosowania prawa.

Trzeba jednak stwierdzić, że piśmiennictwo w polskich czasopismach z dziedziny prawa unijnego nie ogranicza się do powyżej scharakteryzowanego ujęcia. Występują także prace teoretyczne, analizujące cechy prawa unijnego jako systemu prawa, jego aksjologii, pluralizmu konstytucyjnego, metody wykładni i rozumowania stosowane przez Trybunał Sprawiedliwości i sądy itd.

Publikacje z prawa unijnego zawierają często wątki politologiczne i nauk o zarządzaniu, niekiedy nawet dominujące w poszczególnych pracach. Wiąże się to z charakterem Unii Europejskiej jako silnie zintegrowanej organizacji międzynarodowej, o pewnych cechach federacji, w której zachodza różnorodne procesy społeczne i polityczne. Stanowienie i stosowanie prawa to jeden ze sposobów zarządzania taką organizacja, jakkolwiek niejedyny. Spotykane są też w czasopismach prace, w których zagadnienia z prawa unijnego, głównie prawa materialnego, są powiązane z rozważaniami z dziedziny ekonomii.

Nauka prawa unijnego ma niejako z natury rzeczy, ze względu na swój przedmiot, charakter ponadnarodowy. Jest pod tym względem zbliżona do nauki prawa międzynarodowego czy teorii prawa. Z tego względu wiele artykułów w czasopismach z dziedziny prawa unijnego jest przystawalnych do 
publikacji z innych państw i potencjalnie zdolnych do włączenia się do ogólnoeuropejskiego dyskursu naukowego. Na tym polega różnica w porównaniu z innymi dogmatykami prawa, które wykazują związki z krajowymi porządkami prawnymi. Związki te mogą być przełamywane dzięki pracom komparatystycznym albo włączaniu do analiz w szerszym lub węższym zakresie elementów prawa unijnego.

W niektórych publikacjach poświęconych prawu unijnemu występują wyraźne wątki prawa międzynarodowego. Jest tak między innymi w związku z takimi tematami, jak zawieranie przez Unię umów międzynarodowych czy szerzej: stosunki zewnętrzne UE. Dyskutowanym zagadnieniem jest znaczenie, jakie maja dla Unii Europejskiej i dla prawa unijnego europejska Konwencja o ochronie praw człowieka i podstawowych wolności oraz orzecznictwo Europejskiego Trybunału Praw Człowieka. Problem ten bywa omawiany w artykułach w różnych kontekstach, m.in. standardów ochrony praw wynikających z Karty praw podstawowych UE albo z nieudanych jak dotąd planów przystapienia Unii do wspomnianej Konwencji. Innym, nader istotnym problemem z pogranicza prawa unijnego i międzynarodowego jest od kilku lat wystapienie Zjednoczonego Królestwa z Unii Europejskiej (brexit) i jego różnorodne następstwa.

VI. Coraz obszerniejszy i zróżnicowany stawał się na przestrzeni lat krąg tematów będących przedmiotem artykułów z prawa unijnego w czasopismach. Wynika to ze wzrastających zainteresowań badawczych autorów. Przede wszystkim jednak pozostaje to w związku z rozrostem i rozwojem prawa unijnego, które na przestrzeni ostatnich 30 lat znacznie rozszerzyło swój zakres i charakter unormowań. O ile jeszcze w końcu lat osiemdziesiątych prawo wspólnotowe było przede wszystkim prawem gospodarczym, o tyle już kilka lat później Traktat o Unii Europejskiej z Maastricht wprowadził dwa dalsze filary Unii, a mianowicie wspólną politykę zagraniczną i bezpieczeństwa oraz współpracę policyjną i sądową w sprawach karnych. W wyniku kolejnych zmian w traktatach będących podstawą Unii następowała dalsza ekspansja unormowań prawa unijnego. Obecnie prawo to rozciaga się praktycznie na wszystkie gałęzie prawa państw członkowskich, w tym prawa polskiego, jakkolwiek z różną intensywnościa. Obejmuje więc ono między innymi prawo konstytucyjne, administracyjne, finansowe, cywilne, handlowe, własności intelektualnej, pracy, ubezpieczeń społecznych, ochrony środowiska, rolne, a nawet prawo karne.

Nie sposób byłoby wymienić, nie mówiąc już o omówieniu, zagadnień, które są przedmiotem artykułów w czasopismach. Wystarczyć zatem musi naszkicowanie przykładowo jedynie kilku tematów.

Wiele prac dotyczyło kolejnych zmian traktatów założycielskich, które dawały impuls do opisów i analiz tych zmian oraz ich konsekwencji dla stanu Unii i prawa unijnego oraz położenia państw członkowskich, w tym Polski. Artykuły dotyczyły ogólnie zmian traktatowych, albo częściej, wybranych rozwiązań prawnych. Wiele uwagi poświęca się Karcie praw podstawowych UE i różnym aspektom jej stosowania. 
Wśród tematów zawsze aktualnych w artykułach i glosach można wymienić funkcjonowanie Trybunału Sprawiedliwości, a zwłaszcza procedury prejudycjalnej z udziałem sądów krajowych. Doniosłe orzeczenia Trybunału dają niekiedy impuls do poruszania zagadnień o konstytucyjnym znaczeniu. Przykładem tego moga być w ostatnich latach zagadnienia naruszeń praworządności oraz niezależności sądownictwa w niektórych państwach członkowskich, w tym zwłaszcza w Polsce. Zagadnienia te wywołuja zainteresowanie także, albo nawet jeszcze bardziej w związku z działalnością innych instytucji unijnych, np. z postępowaniem na podstawie art. 7 Traktatu o Unii Europejskiej.

Ponieważ jedna z naczelnych wartości Unii Europejskiej jest ochrona praw podstawowych jednostek, problematyka z tym związana jest przedmiotem zainteresowania piśmiennictwa w różnych kontekstach. Tytułem przykładu można wymienić wiele artykułów z ostatnich lat poświęconych rozporządzeniu Parlamentu Europejskiego i Rady z 2016 r. w sprawie ochrony osób fizycznych w związku z przetwarzaniem danych osobowych i w sprawie swobodnego przepływu takich danych, czyli ogólnego rozporzadzenia o ochronie danych (RODO). Innym tematem będącym przedmiotem licznych prac jest europejski nakaz aresztowania. Temu zagadnieniu, mającemu podstawe prawną w decyzji ramowej z 2002 r., poświęcono artykuły i glosy na przestrzeni kilkunastu lat. Ostatnimi czasy owa problematyka nabrała na nowo aktualności w związku z wyrokami Trybunału Sprawiedliwości i sądów niektórych państw członkowskich. Wyroki te wiązały się z watpliwościami co do dopuszczalności zawieszenia procedury przekazania osób podejrzanych lub skazanych do Polski w wykonaniu europejskich nakazów aresztowania wobec naruszania w naszym kraju zasad praworządności i niezawisłości sędziowskiej.

Większa część piśmiennictwa w czasopismach jest poświęcona rozmaitym zagadnieniom prawa materialnego, głównie prawa gospodarczego. Niektóre tematy zyskują na popularności w związku z planowanymi lub przeprowadzonymi zmianami w prawie unijnym, zwłaszcza gdy te zmiany mają daleko idące konsekwencje w państwach członkowskich, w tym także w Polsce. Tytułem przykładu można podać zagadnienia reformy położenia tzw. pracowników delegowanych do innych państw członkowskich.

Oprócz artykułów z dziedziny prawa unijnego duży udział w czasopismach maja glosy do orzeczeń Trybunału Sprawiedliwości UE. Wiąże się to z charakterem prawa unijnego jako w dużej mierze prawa pretorskiego. Występuja także regularne lub okresowe przeglądy orzecznictwa unijnego.

VII. Należy wyraźnie zaakcentować, że w ramach omawianej tu problematyki odzwierciedlenia prawa unijnego w czasopismach mieści się także, jako jej obszerny, a może nawet dominujacy segment, problematyka prawa polskiego w powiązaniu z prawem unijnym. Takie powiązanie jest wyraźne i zrozumiałe, jeśli się pamięta, że po przystapieniu Polski do Unii prawo unijne stało się częścią obowiązującego w naszym państwie porządku prawnego. 
Można zaryzykować tezę, że trudno jest zajmować się dzisiaj na dłuższa metę dogmatyka prawa polskiego bez uwzględniania prawa unijnego. Przeniknęło ono zasadniczo wszystkie dziedziny prawa, jakkolwiek w różnym stopniu. Nastapiło to w miarę rozszerzania się zakresu unormowań prawa UE również na te dziedziny, które jeszcze pod koniec lat osiemdziesiątych były wyłącznie przedmiotem krajowych unormowań.

W czasopismach spotyka się różne sposoby uwzględniania prawa polskiego i prawa unijnego w ramach poszczególnych artykułów lub glos. Niektóre prace sa poświęcone głównie prawu polskiemu, a prawo unijne pojawia się w nich dodatkowo jako element kontekstu prawnego, kształtujący mniej lub bardziej treść prawa polskiego. Jest tak zwłaszcza w częstych sytuacjach, kiedy dana dziedzina unijnego prawa materialnego jest normowana w dyrektywach unijnych, które podlegają implementowaniu do polskiego prawa. W innych przypadkach jest inaczej, tj. prawo unijne wybija się w publikacjach na pierwszy plan, a prawo polskie jest traktowane jako uzupełniające. Taka sytuacja występuje wówczas, gdy przedmiotem publikacji w czasopismach sa normy traktatów albo rozporządzeń unijnych, które są uzupełniane przez polskie ustawy.

$\mathrm{W}$ wielu dziedzinach europeizacja prawa polskiego jest tak daleko posunięta, że nie jest możliwe analizowanie rozwiązań prawnych obowiązujących w naszym kraju bez szerokiego odwoływania się do prawa unijnego. Uzasadnione jest przedstawianie tak ukształtowanego porządku prawnego jako spójnej całości, chociaż złożonej z różnych składników: norm należących do prawa polskiego i unijnego.

Zawsze aktualne są zagadnienia ustrojowe, na przykład dotyczące relacji prawa unijnego do prawa polskiego. Mieszczą się tu artykuły na temat rozumienia i zakresu obowiązywania zasady pierwszeństwa prawa unijnego, rozpatrywanej z perspektywy prawa unijnego albo z perspektywy Konstytucji RP. Innym zagadnieniem ustrojowym omawianym $\mathrm{w}$ piśmiennictwie sa relacje między kompetencjami Trybunału Sprawiedliwości, a Trybunału Konstytucyjnego i sądów.

Oprócz artykułów są publikowane w czasopismach glosy do orzeczeń Trybunału Konstytucyjnego lub sądów, zwłaszcza najwyższych (SN, NSA), w których występują obok problemów prawa polskiego również zagadnienia prawa unijnego, często poddane wcześniej interpretacji przez Trybunał Sprawiedliwości. Znaczenie elementów unijnych dla rozstrzygnięć i tym samym także dla glosatorów jest różne. W szczególności prawo unijne może być bezpośrednio lub pośrednio (poprzez prawo polskie implementujące prawo unijne) podstawą orzekania przez polskie sądy. Kiedy indziej prawo unijne weryfikuje tezy oparte na prawie polskim.

VIII. Powyższe obserwacje nie daja jeszcze podstaw do formułowania wniosków o poziomie piśmiennictwa $\mathrm{z}$ dziedziny prawa unijnego $\mathrm{w}$ czasopismach albo o jego przydatności dla rozwoju nauki prawa w naszym kraju i jej wkładu do nauki europejskiej. Wyraźny jest natomiast korzystny wpływ omawianych publikacji na lepsze poznanie omawianej dziedziny i na stosowanie prawa w Polsce. 


\section{EUROPEAN UNION LAW IN POLISH LEGAL JOURNALS (SOME OBSERVATIONS)}

\section{Sum mary}

There has been a growth of interest in EU law (formerly Community law) in Polish legal periodicals ever since the political changes in 1989 made it possible for Poland to formally participate in the processes of European integration. Few journals in Poland are devoted exclusively or predominantly to EU law. However, there are many journals publishing articles covering various areas of law, including EU law. The majority of these journals are in Polish, but the number of those published in English is increasing. Occasionally, some issues or individual articles in Polish journals are published in English. The circle of authors is diverse. It includes both persons specializing in EU law and authors dealing with various areas of Polish law analysed in close connection with EU law. The articles deal with problems of EU institutional law, but also with various aspects of substantive law. The jurisprudence of the CJEU is also extensively analysed. The influence of such journals, in terms of gaining a better understanding of the role of EU law in the process of making and applying the law in Poland, is now evident.

Keywords: Polish legal journals; EU law in Polish legal journals; articles in English in Polish legal journals 